\title{
Microbial Screening for Biotransformation of Glycyrrhizin into 18 $\alpha$-Glycyrrhetinic Acid and 18ß-Glycyrrhetinic Acid and their HPLC Analysis
}

\author{
Ambika Chamoli ${ }^{1}$, Mojeer Hasan', Makhmur Ahmad ${ }^{2 *}$, Mohd Rashid $^{3}$, Babar Ali ${ }^{3}$ and Bibhu Prasad Panda ${ }^{1}$ \\ ${ }^{1}$ Microbial and Pharmaceutical Biotechnology Laboratory, Center for Advanced Research in Pharmaceutical Sciences, School of Pharmaceuti- \\ cal Education and Research, Jamia Hamdard, New Delhi, India \\ ${ }^{2}$ Department of Pharmaceutics, College of Dentistry and Pharmacy, Buraydah, Al-Qassim, Kingdom of Saudi Arabia \\ ${ }^{3}$ Department of Pharmacognosy and Pharmaceutical Chemistry, College of Dentistry and Pharmacy, Buraydah, Al-Qassim, Kingdom of Saudi \\ Arabia \\ *Corresponding Author: Mohammad Makhmur Ahmad, Assistant Professor (Pharmaceutical Microbiology), Department of \\ Pharmaceutics, College of Dentistry and Pharmacy, Buraydah, Al-Qassim, Kingdom of Saudi Arabia.
}

Received: September 25, 2019; Published: October 15, 2019

DOI: 10.31080/ASMI.2019.02.0400

\begin{abstract}
Glycyrrhizin is the main compound of Glycyrrhiza glabra which can be biotransformed into $18 \alpha$-glycyrrhetinic acid and $18 \beta$-glycyrrhetinic acid for diverse therapeutic properties. In the present study different microbial strains were screened for highest $\beta$-glucuronidase enzyme activity for biotransformation of glycyrrhizin into $18 \alpha$-glycyrrhetinic acid and $18 \beta$-glycyrrhetinic acid. The maximum enzyme activity $(62.126 \mathrm{U} / \mathrm{ml})$ was obtained from sonicated Escherichia coli MTCC 1652 among all the microbial strains. The highest concentration of $18 \alpha$-glycyrrhetinic acid and $18 \beta$-glycyrrhetinic acid from sonicated $E$. coli was found to be $705.985 \mu \mathrm{g} /$ $\mathrm{ml}$ and $133.036 \mu \mathrm{g} / \mathrm{ml}$ respectively. However, among all the fungal strains, sonicated Penicillium citrinum has produced maximum (37.012 U/ml) $\beta$-glucuronidase activity with concentration of $120.601 \mu \mathrm{g} / \mathrm{ml} 18 \alpha$-GA and 9.513 $\mu \mathrm{g} / \mathrm{ml} 18 \beta$-GA. Penicillium chrysogenum have produced maximum amount of $217.799 \mu \mathrm{g} / \mathrm{ml}$ and $46.9856 \mu \mathrm{g} / \mathrm{ml}$ of $18 \alpha$-GA and $18 \beta$-GA respectively with lower (21.329 $\mathrm{U} / \mathrm{ml}$ ) $\beta$-glucuronidase activity. The present study could be applied as potential source of simultaneous production of plant phytomolecules which has tremendous health benefit.

Keywords: Glycyrrhizin; $\beta$-glucuronidase; $18 \alpha$-glycyrrhetinic Acid; $18 \beta$-glycyrrhetinic Acid; Escherichia coli; Penicillium citrinum
\end{abstract}

\section{Introduction}

Glycyrrhiza glabra (Fabaceae), commonly known as licorice, is widely used in Indian system of medicine for the treatment of various disease. Roots and stems of Glycyrrhiza glabra has main active constituent glycyrrhizin (GL), a triterpenoids saponin. GL is the major bioactive compound of licorice and has been recommended for prevention of hepatic lipotoxicity, chronic hepatitis C, and lipopolysaccharide- (LPS-) induced inflammation [1-3]. GL exhibits bioactive properties through the functions of its biologically active metabolite, $18 \beta$-glycyrrhetinic acid (GA), which is produced via enzymatic hydrolysis [1]. GA is mainly used for its multiple functions such as anti-tumour, anti-virus, antibacterial and as antioxidant in processed food. GA can exist as trans and cis isomers, the transform $18 \alpha$-glycyrrhetinic acid and the cis form $18 \beta$-glycyrrhetinic acid [4-6]. Both of isomers showed biological activity but $18 \beta$-glycyrrhetinic acid has been more extensively studied because of its abundance in root extract. Hence it was widely believed that $18 \beta$-glycyrrhetinic acid has more biological activity, than $18 \alpha$-glycyrrhetinic acid $[7,8]$.
In the past decade set, several studies have demonstrated that microbial transformation is a versatile tool to enlarge the structural diversity of triterpenoids [9]. Biocatalysis and biotransformation have many advantages, such as high substrate specificity and mild reaction conditions [4]. A great challenge for the realization of a desired biotransformation is finding the appropriate microorganism. Thus, classical screening of a series of microbial strains is still the most widely used technique. Very recently, a comprehensive review on microbial transformation of triterpenoids was published [10]. Isolation of Aspergillus parasiticus producing $\beta$-glucuronidase was screened and enzyme activity was determined by using phenolphthalein- $\beta$-D-glucuronide (PPG) [11]. Enzymatic conversion of glycyrrhizin of G. glabra into GA using commercial preparation from Aspergillus niger was also reported [12]. Due to structural similarity of GL and GA to steroids, they have mineralocorticoid like effects and inhibit metabolic enzymes for adrenocorticosteroids [13]. GL is found naturally as $\beta$-isomer (18 $\beta$-GL, 18 $\beta$-GA) which can be isomerized to their $\alpha$-isomers (18 $\alpha$-GL, $18 \alpha-\mathrm{GA})$ under alkaline condition [14]. Stereochemistry play important role for different biological and physicochemical properties of $18 \alpha-\mathrm{GA}$ and $18 \beta-\mathrm{GA}$ 
[15]. Screening of different microbial strains is required to investigate the presence of $\beta$-glucuronidase enzyme for bioconversion of GL into $18 \alpha-G A$ and $18 \beta-G A$.

The present study focused on screening of different bacterial and fungal strains for higher activity of $\beta$-glucuronidase enzyme and for conversion of GL into $18 \alpha$-glycyrrhetinic acid and $18 \beta$-glycyrrhetinic acid in fermented G. glabra root extract. Biotransformed compounds were analysed by high performance liquid chromatography (HPLC) method.

\section{Materials and Methods}

Microorganism

Seven fungal strains and two bacterial strains were taken for screening. Fungal strains Penicillum chrysogenum MPBL1 and Rhizopus oryzae MPBL2 were isolated from the soil and identified in Indian Agriculture Research Institute, Pusa, New Delhi. Monascus purpureus 369 and Monascus purpureus 410 fungal strains were obtained from Institute of Microbial Technology (IMTECH), Chandigarh, India. Rhizopus oligosporous NCIM1215 and Penicillum citrinum NCIM 768 were received from National Collection of Industrial Microorganism (NCIM), Pune, India. Monascus pilosus CBS290.34 was obtained from American Type Culture Collection (ATCC). All the fungal strains were grown and maintained in Potato Dextrose Agar (PDA) slants and subcultured every 30 days. The bacterial strain Escherichia coli MTCC 1652 and Bacillus subtilis MTCC 2616 were taken from the Institute of Microbial Technology (IMTECH), Chandigarh, India which were grown and maintained in Nutrient Agar (NA) and subcultured every 30 days.

\section{Preparation of seed culture}

Spore suspension of Penicillum chrysogenum MPBL1, Rhizopus oryzae MPBL2, Monascus purpureus 369, Monascus purpureus 410, Rhizopus oligosporous NCIM 1215, Penicillum citrinum NCIM 768 was prepared from actively growing slants in sterile water and diluted to a concentration $5.7 \times 10$. Spore counting was carried out by using hemocytometer. Spore suspension (15\%) was inoculated to conical flasks containing the potato dextrose broth (PDB). These culture was inoculated at $27^{\circ} \mathrm{C}$ for $48 \mathrm{hrs}$ in a shaker incubator at $110 \mathrm{rpm}$. Bacterial seed culture of Escherichia coli MTCC 1652 and Bacillus subtilis MTCC 2616 were prepared by culturing bacterial inoculums in nutrient broth (NB) for $48 \mathrm{hrs}$ at $37^{\circ} \mathrm{C}$ at $150 \mathrm{rpm}$ in rotary shaker.

\section{Preparation of Glycyrrhiza glabra root extract}

G. glabra roots were cleaned, dried and milled to prepare coarse powder. Twenty-five grams of coarse powder were extracted with soxhlet apparatus by using $100 \%$ water for $72 \mathrm{hr}$. The extract was concentrated under reduced pressure in rotary evaporator at $40^{\circ} \mathrm{C}$.

Biotransformation of glycyrrhizin to $18 \alpha$-glycyrrhetinic acid and 18ß-glycyrrhetinic acid

Submerged biotransformation of GL was carried out in $250 \mathrm{ml}$ Erlenmeyer conical flask. Czapedox medium of pH 5.5 was pre- pared and sterilized at $121^{\circ} \mathrm{C}$ and $1.06 \mathrm{Kg} / \mathrm{cm} 2$ for $20 \mathrm{~min}$. The fungal seed culture $(5 \mathrm{ml})$ was inoculated to Czapedox medium and biotransformation of all fungal strains was carried out at $27^{\circ} \mathrm{C}$ and $110 \mathrm{rpm}$ for $96 \mathrm{hrs}$. Synthetic media was prepared and $\mathrm{pH}$ was adjusted to 7.2. Bacterial seed culture ( $5 \mathrm{ml}$ ) was inoculated to $50 \mathrm{ml}$ of synthetic media and bacterial biotransformation was carried out at $37^{\circ} \mathrm{C}$ and $150 \mathrm{rpm}$ for $24 \mathrm{hrs}$ [16].

\section{Screening of bacterial and fungal strains}

The fungal and bacterial strains were screened on the basis of $\beta$-glucuronidase enzyme activity and their bioconversion capability. These microbial strains were assayed in two ways: non-sonication and sonication. Fermented broth was sonicated with the help of probe sonicator to disrupt the cells so that entire enzyme can be leaked out and a part of fermented broth was kept as non-sonicated. The enzyme activity was performed by HPLC method [17].

\section{$\beta$-glucuronidase enzyme assay}

Hydrolytic Unit (HU) was used for enzyme activity by incubating the enzyme with $3 \mathrm{Mm}$ GL solution at $35^{\circ} \mathrm{C}$ for $10 \mathrm{~min}$. The enzyme reaction was stopped by adding $200 \mathrm{mM}$ glycine buffer solution of pH 10.4. The amount of $18 \alpha-G A$ and $18 \beta-G A$ was analysed by HPLC. Here one $\mathrm{HU}$ is defined as weight of $18 \alpha-\mathrm{GA}$ and $18 \beta$-GA in microgram released from $1 \mu \mathrm{g} / \mu \mathrm{l}$ of pure GL solution in $10 \mathrm{~min}$ [18].

\section{Extraction of GL, $18 \alpha-\mathrm{GA}$ and $18 \beta-\mathrm{GA}$}

The fermented broth was subjected to sonication for $10 \mathrm{~min}$. The disrupted cell was then centrifuged at $5000 \mathrm{rpm}$ for $10 \mathrm{~min}$. Supernatant having 18 $\alpha$-GA, 18 $\beta$-GA and unconverted GL was filtered and analysed by HPLC [17].

Chromatographic condition and analysis of GL, 18 $\alpha-\mathrm{GA}$ and 18ß-GA

The analysis of GL was performed by high performance liquid chromatography (HPLC) method. The chromatography was carried out by RP C18 column. The mobile phase consists of methanol: water $(85: 15 \mathrm{v} / \mathrm{v})$ at a flow rate of $1 \mathrm{ml} / \mathrm{min}$ with run time of 10 min and detection was carried out at $254 \mathrm{~nm}[11,18]$. Simultaneous analysis of $18 \alpha$-GA acid ( $20 \mu \mathrm{l})$ and $18 \beta-\mathrm{GA}(20 \mu \mathrm{l})$ was performed by HPLC method. The mobile phase was used acetonitrile: tetrahydrofuran: water (10: 80: $10 \mathrm{v} / \mathrm{v}$ ) at flow rate of $1 \mathrm{ml} / \mathrm{min}$ with run time of $10 \mathrm{~min}$. The UV detection was carried out at $254 \mathrm{~nm}$ [19].

\section{Results and Discussion}

Bioconversion of glycyrrhizin to $18 \alpha-\mathrm{GA}$ and $18 \beta-\mathrm{GA}$

Bioconversion from enzymatic approach is better than traditional chemical method as the sugar molecules can be removed from the glycoside in mild reaction conditions and the formation of by-products can be avoided. Bioconversions of GL into GA have already been carried out by using enzymes derived from animal livers and human intestinal bacteria [11]. $\beta$-glucuronidases enzymes are members of the glycosidase family 2 of enzymes that hydrolyse the glycosidic bond between two or more carbohydrate or between a carbohydrate and noncarbohydrate moiety [20]. In 
64

the present study enzymatic conversion of glycyrrhizinic acid (GL), from root extract of Glycyrrhiza glabra L., into $18 \alpha$-GA and $18 \beta-\mathrm{GA}$, was achieved by using $\beta$-glucuronidase from different microbial strains.

E. coli, B. subtilis, P. chrysogenum, R. oryzae, P. citrinum, M. purpureus 369 , M. purpureus $410, R$. oligosporous and M. pilosus were screened on the basis of their $\beta$-glucuronidase enzyme activity (Table 1, Figure 2) and their bioconversion capability (Table 2, Figure 2). All the standard chromatograms are shown in figure 1. Enzyme activity of sonicated bacterial strain was found to be higher than non sonicated bacterial strain. The maximum enzyme activity $(62.126 \mathrm{U} / \mathrm{ml})$ was obtained from sonicated E. coli MTCC 1652 as compared to sonicated B. subtilis $(19.536 \mathrm{U} / \mathrm{ml})$. However, among all the fungal strains, sonicated $P$. citrinum produced maximum $\beta$-glucuronidase activity $(37.012 \mathrm{U} / \mathrm{ml})$. All the sonicated fungal strains have produced higher quantity of $\beta$-glucuronidase enzyme activity as compare to non-sonicated fungal strains except $R$. oligosporous and M. purpureus. Higher enzyme activity of sonicated bacterial and fungal strains might be due to presence of $\beta$-glucuronidase as an intracellular enzyme.

\begin{tabular}{|l|c|c|}
\hline \multirow{2}{*}{\multicolumn{1}{|c|}{ Microbial Strains }} & \multicolumn{2}{|c|}{ /-glucuronidase (Unit/ml) } \\
\cline { 2 - 3 } & $\begin{array}{c}\text { Non-Sonicated } \\
\text { (NS) }\end{array}$ & Sonicated (S) \\
\hline E. coli MTCC 1652 & 23.419 & 62.126 \\
\hline B. subtilis 2616 & 17.235 & 19.536 \\
\hline P. chrysogenum MPBL 1 & 19.166 & 21.329 \\
\hline P. citrinum NCIM 768 & 32.219 & 37.012 \\
\hline R. oryzae MPBL 2 & 23.085 & 33.129 \\
\hline R. oligosporous NCIM 1215 & 33.356 & 27.174 \\
\hline M. purpureus MTCC 369 & 33.009 & 27.272 \\
\hline M. purpureus 410 & 10.108 & 17.437 \\
\hline M. pilosus ATCC CBS 290.34 & 15.531 & 17.721 \\
\hline
\end{tabular}

Table 1: Concentration of $\beta$-glucuronidase enzyme under submerged biotransformation process.

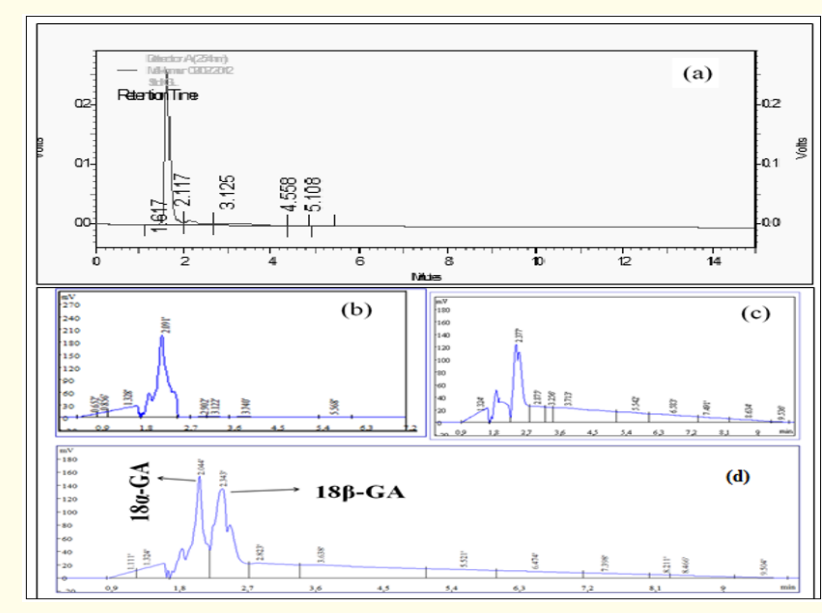

Figure 1: HPLC chromatogram of standard glycyrrhizin (a), $18 \alpha$-glycyrrhetinic acid (b), 18ß-glycyrrhetinic acid (c) and standard mixture of $18 \alpha-G A$ and $18 \beta-G A(d)$.

\begin{tabular}{|c|c|c|c|c|c|}
\hline \multirow{2}{*}{$\begin{array}{l}\text { Microbial } \\
\text { Strains }\end{array}$} & \multirow{2}{*}{$\begin{array}{c}\text { GL } \\
(\mu \mathrm{g} / \mathrm{ml})\end{array}$} & \multicolumn{2}{|c|}{$\begin{array}{c}\text { Sonicated (S) } \\
(\mu \mathrm{g} / \mathrm{ml})\end{array}$} & \multicolumn{2}{|c|}{$\begin{array}{l}\text { Non-sonicated } \\
(\mathrm{NS})(\mu \mathrm{g} / \mathrm{ml})\end{array}$} \\
\hline & & $18 \alpha-G A$ & 18ß-GA & $18 \alpha-G A$ & $18 \beta-G A$ \\
\hline $\begin{array}{l}\text { E. coli MTCC } \\
1652\end{array}$ & 70.499 & 705.985 & 133.036 & 266.133 & 37.698 \\
\hline $\begin{array}{l}\text { B. subtilis } \\
\text { MTCC } 2616\end{array}$ & 43.900 & 202.00 & 14.132 & 195.860 & 14.048 \\
\hline $\begin{array}{l}\text { P. chrysoge- } \\
\text { num MPBL } 1\end{array}$ & 45.366 & 202.375 & 46.985 & 217.799 & 14.744 \\
\hline $\begin{array}{l}\text { P. citrinum } \\
\text { NCIM } 768\end{array}$ & 52.103 & 120.601 & 9.513 & 166.131 & 14.194 \\
\hline $\begin{array}{l}\text { R. oryzae } \\
\text { MPBL } 2\end{array}$ & 48.311 & 176.476 & 13.355 & 162.388 & 8.320 \\
\hline $\begin{array}{l}\text { R. oligospo- } \\
\text { rous NCIM } \\
1215\end{array}$ & 39.929 & 108.805 & 10.289 & 179.047 & 13.146 \\
\hline $\begin{array}{l}\text { M. purpureus } \\
\text { MTCC } 369\end{array}$ & 30.628 & 109.915 & 8.656 & 147.830 & 7.631 \\
\hline $\begin{array}{l}\text { M. purpureus } \\
\text { MTCC } 410\end{array}$ & 91.965 & 198.150 & 11.471 & 114.872 & 13.682 \\
\hline $\begin{array}{l}\text { M. pilosus } \\
\text { ATCC CBS } \\
290.34\end{array}$ & 56.877 & 101.378 & 9.956 & 176.497 & 5.570 \\
\hline
\end{tabular}

Table 2: Concentration of glycyrrhizin, $18 \alpha$-glycyrrhetinic acid and $18 \beta$-glycyrrhetinic acid under submerged biotransformation process by different microbial strains.

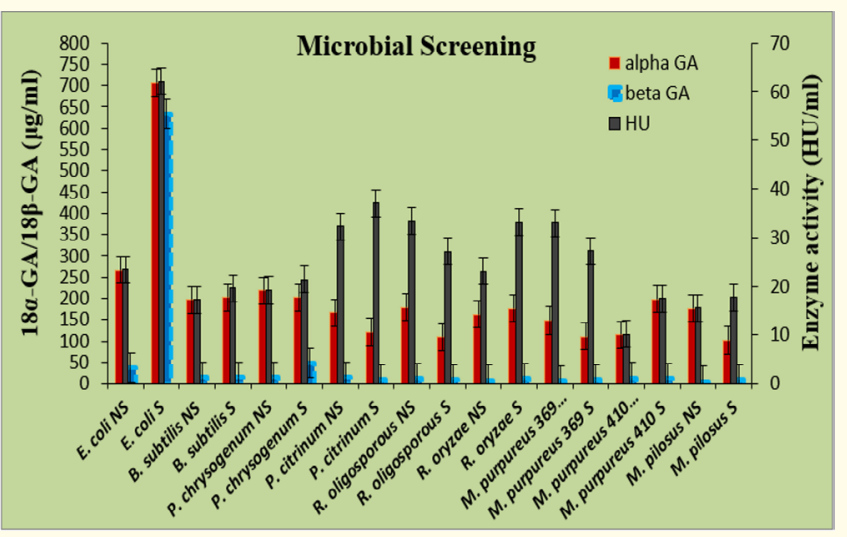

Figure 2: Screening of different microbial strains.

Quantitative determination of $18 \alpha-\mathrm{GA}$ acid and $18 \beta$-GA was carried out by using a HPLC with RP C18 column. and an UV detector operating at $254 \mathrm{~nm}$ (Figure 1). The highest concentration of $18 \alpha$-GA and 18ß-GA from sonicated E. coli was found to be 705.985 $\mu \mathrm{g} / \mathrm{ml}$ and $133.036 \mu \mathrm{g} / \mathrm{ml}$ respectively. This may be due to higher enzyme activity of $E$. coli. Among all the fungal strains, P. chrysogenum have produced maximum of $217.799 \mu \mathrm{g} / \mathrm{ml}$ (non sonicated) and $46.9856 \mu \mathrm{g} / \mathrm{ml}$ (sonicated) of $18 \alpha-\mathrm{GA}$ and $18 \beta$-GA respectively. Sonicated R. oligosporous and M. purpureus have produced almost equal quantity of $18 \alpha$-GA. Non-sonicated B. subtilis, P. chrysogenum and $P$. citrinum have also produced almost equal concentration of 18ß-GA. Non-sonicated M. purpureus and M. pilosus have produced $7.631 \mu \mathrm{g} / \mathrm{ml}$ and $5.570 \mu \mathrm{g} / \mathrm{ml}$ of $18 \beta-\mathrm{GA}$ respectively (Table 2, Figure 2). 
Earlier it has been reported that sonication cause cell lysis and release of intracellular enzyme in soil [21]. Short time sonication is responsible for activation of extracellular enzymes while long time sonication would lyse the microbial cell and release the intracellular enzymes [22]. Our results also suggest that sonication might be a promising factor for differentiating between extracellular and intracellular enzyme activity.

\section{Conclusion}

Biotransformation of natural compounds is an important tool to produce various new phyomolecules which may be used in different diseases. In the present study nine microbial strains (bacterial and fungal) were screened for biotransformation of GL to $18 \alpha-\mathrm{GA}$ and $18 \beta-\mathrm{GA}$ in Glycyrrhiza glabra root extract. Result showed that sonicated $E$. coli produced maximum bioconversion as compared to all microbial strains. Sonicated E. coli was found to be the best source of $\beta$-glucuronidase enzyme for biotransformation among all the microbial strains. It was found that bacterial strains produced higher amount of $\beta$-glucuronidase enzyme than fungal strains during submerged biotransformation process. As the microbial $\beta$-glucuronidase enzyme is an intracellular enzyme, it is very important to understand its role in hydrolysis of glycyrrhizin molecule during biotransformation process. Moreover, biotransformation processes depend upon various factors including microorganism, media components, $\mathrm{pH}$ and temperature [23,24]. Therefore, exact mechanism of microbial biotransformation needs to be verified.

\section{Bibliography}

1. Wu X., et al. "Prevention of free fatty acid-induced hepatic lipotoxicity by 18beta-glycyrrhetinic acid through lysosomal and mitochondrial pathways". Lipotoxicity 47 (2008): 1905-1915.

2. Wang C Y., et al. "Glycyrrhizic acid and 18ß-glycyrrhetinic acid modulate lipopolysaccharide-induced inflammatory response by suppression of NF- $\mathrm{KB}$ through PI3K p110 $\delta$ and $\mathrm{p} 110 \gamma$ inhibitions". Journal of Agriculture and Food Chemistry 59 (2011): 7726-7733.

3. Rossum V T., et al. "Glycyrrhizin as a potential treatment for chronic hepatitis C". Alimentary Pharmacology and Therapeutics 12 (1998): 199-205.

4. $\quad$ Feng S J., et al. "Screening strains for directed biosynthesis of $\beta$-D-mono-glucuronide-glycyrrhizin and kinetics of enzyme production". Journal of Molecular Catalysis B: Enzymatic 43 (2006): 63-67.

5. Zeng C X., et al. "A comparison of the distribution of two glycyrrhizic acid epimers in rat tissues". European Journal of Drug Metabolism and Pharmacokinetics 31 (2006): 253-258.

6. Ha Y M., et al. "Chiral separation of glycyrrhetinic acid by highperformance liquid chromatography". Journal of Pharmaceutical and Biomedical Analysis 9 (1991): 805-809.
7. Rossi T., et al. "Selectivity of action of glycyrrhizin derivatives on the growth of MCF-7 and HEP-2 cells". Anticancer Research 23 (2003): 3813-3818.

8. Amagaya S., et al. "Comparative studies of the stereoisomers of glycyrrhetinic acid on anti-inflammatory activities". Journal of Pharmacobiodynamics 7 (1984): 923-928.

9. Parra A., et al. "Microbial transformation of triterpenoids". Mini Reviews in Organic Chemistry 6 (2009): 307-320.

10. Wang J., et al. "Bioconversion of glycyrrhizinic acid in liquorice into 18- $\beta$-glycyrrhetinic acid by Aspergillus parasiticus speare BGB". Applied Biochemistry and Microbiology 46 (2010): 421466.

11. Morana A., et al. "Enzymatic production of 18- $\beta$-glycyrrhetinic acid G. glabra L". Biotechnology Letters 24 (2002): 1907-1911.

12. Ahmad M and BP Panda. "Alginate Immobilization of Escherichia coli MTCC 1652 whole cells for bioconversion of glycyrrhizinic acid and into 18- $\beta$ glycyrrhetinic acid". Pakistan Journal of Biological Sciences 16 (2013): 2046-2049.

13. Chamoli A., et al. "Simultaneous determination of $18 \alpha$-glycyrrhetinic acid and 18ß-glycyrrhetinic acid in Glycyrrhiza glabra root by reversed phase high performance liquid chromatography". Drug Development and Therapeutics 7 (2016): 59-62.

14. Spizzizen J., et al. "Biochemical studies on the phenomenon of virus reproduction: III. The inhibition of coliphage T2r+ multiplication by sodium salicylate and sodium gentisate". Journal of Bacteriology 62 (1951): 323-329.

15. WANG Z Y., et al. "Inhibition of mutagenicity in Salmonella typhimurium and skin tumor initiating and tumor promoting activities in SENCAR mice by glycyrrhetinic acid: comparison of 18-alpha and 18-beta stereoisomers". Carcinogenesis 12 (1991): 187-192.

16. Kaisha MK. U.K Patent. 2071665: 1983.

17. Ahmad M., et al. "Screening and bioconversion of glycyrrhizin of Glycyrrhiza glabra root extract to $18-\beta$ glycyrrhetinic acid by different microbial strain". Drug Development Therapeutics 7 (2016): 69-72.

18. Nocca G., et al. "Quantitative determination of 18- $\beta$-glycyrrhetinic Acid in HepG2 cell line by High Performance Liquid Chromatography method". International Journal of Analytical Chemistry 2018 (2018): 1-5.

19. Kondo M., et al. "Physiochemical properties and applications of $\alpha$ and $\beta$ glycyrrhizins, natural surface active agents in licorice root extract". Journal of the Society of Cosmetic Chemist 37 (1986): 177-189. 
20. Amin HAS., et al. "Biosynthesis of glycyrrhetinic acid 3-0mono- $\beta$-d-glucuronide by free and immobilized Aspergillus terreus $\beta$-d-glucuronidase". Journal of Molecular Catalysis B: Enzymatic 69 (2011): 54-59.

21. Cesare F., et al. "Use of sonication for measuring acid phosphatase activity in soil". Soil Biology and Biochemistry 32 (2000): 825-832.

22. Qin S., et al. "Differentiating intracellular from intracellular alkaline phosphatase activity in soil by sonication". Plose One 8 (2013): e58691.

23. El-Refai A H., et al. "Physiological and chemical studies on the bioconversion of glycyrrhizin by Aspergillus niger NRRL 595". Malaysian Journal of Microbiology 6 (2012): 75-82.

24. Manosroi J., et al. "Factors affecting the biotransformation of chlormadinone acetate to delmadinone acetate". Journal of Molecular Catalysis B: Enzymatic 23 (2003): 37-42.

Volume 2 Issue 11 November 2019

(C) All rights are reserved by Makhmur Ahmad., et al. 